\title{
The effect of heather supplementation on gastrointestinal nematode infections and performance in Cashmere and local Celtiberic goats on pasture
}

\author{
K. Osoro ${ }^{\mathrm{a}, *}$, A. Benito-Peña ${ }^{\mathrm{b}}$, P. Frutos ${ }^{\mathrm{c}}, \mathrm{U}_{\text {. García }}^{\mathrm{a}}$, \\ L.M. Ortega-Mora ${ }^{b}$, R. Celaya ${ }^{a}$, I. Ferre $^{b}$ \\ a Servicio Regional de Investigación y Desarrollo Agroalimentario (SERIDA), Área de Sistemas de Producción Animal, \\ Consejería de Medio Rural y Pesca, Principado de Asturias, 33300 Villaviciosa, Spain \\ ${ }^{\mathrm{b}}$ Departamento de Sanidad Animal, Facultad de Veterinaria, Universidad Complutense de Madrid, \\ Ciudad Universitaria s/ $n$, 28040 Madrid, Spain \\ c Estación Agrícola Experimental, Consejo Superior de Investigaciones Científicas (CSIC), \\ Apdo 788, 24080 León, Spain
}

Received 26 May 2005; received in revised form 29 August 2005; accepted 30 September 2005

Available online 28 November 2005

\begin{abstract}
A study was performed on 48 adult dry goats (16 local Celtiberic and 32 Cashmere does) at pasture and naturally infected with gastrointestinal nematodes to investigate the effects of heather supplementation on faecal egg count(s) (FEC) and live weight changes. The experiment was carried out in a mountain area in the north-west of Spain from June to November in 2003. Two plots of 10,550 and $9,050 \mathrm{~m}^{2}$ with perennial ryegrass/white clover (Lolium perenne/Trifolium repens) pastures were established and a total of 24 goats ( 8 local Celtiberic does and 16 Cashmere does) were randomly allocated to each plot. The trial consisted of comparing live weight changes and FECs in goats fed heather supplement (treated group) or not (control group). A supplement of freshly cut heather was offered ad libitum to the treated group every 3 days in the morning. Cashmere does showed a significantly $(P<0.001)$ lower live weight decrease than the Celtiberic goats. The goats supplemented with heather showed a lower FEC than compared controls and this effect was significant $(P<0.05)$ in August and in the following controls (September, October and November). Two goats died before November in the control group. In conclusion, it seems that the availability of heather reduces the FEC in goats grazing ryegrass/white clover pastures and tends to improve their live weights.
\end{abstract}

(C) 2005 Elsevier B.V. All rights reserved.

Keywords: Goat breed; Grazing; Heather; Gastrointestinal nematodes; Live weight

\section{Introduction}

Gastrointestinal parasitism reduces the efficiency of production of grazing ruminants and has detrimental

\footnotetext{
* Corresponding author. Tel.: +34 985890066; fax: +34 985891854 .

E-mail address: kosoro@serida.org (K. Osoro).
}

effects on their welfare. The traditional way to control these parasitic infections is the repeated administration of anthelmintic drugs integrated, where practical, with grazing and management strategies. Frequent treatment with anthelmintic drugs has led, however, to a widespread development of anthelmintic resistant strains of nematodes, particularly in sheep and goats, in both the northern and southern hemi- 
spheres (Jackson and Coop, 2000). Furthermore, there is increasing public concern over drug residues in meat and milk products, and a potential risk for environmental contamination (McKellar, 1997). Host nutrition can directly affect gastrointestinal nematodes through the ingestion of plant compounds or nutrients that may either penalize parasite fitness or alter the gut (nutritional) environment in which the parasites reside (Houdijk and Athanasiadou, 2003). The use of forages or plants with anthelmintic properties (e.g. tanninrich plants) has been proposed as an alternative control strategy to reduce the impact of parasitism and the extent of anthelmintic resistance (Athanasiadou et al., 2003).

Condensed tannins (CT) have been reported to be able to benefit ruminant nutrition by increasing postruminal protein availability (Waghorn et al., 1987) and reducing the consequences of gastrointestinal nematode parasitism (Athanasiadou et al., 2000a,b; Coop and Kyriazakis, 2001). Most studies on the anthelmintic properties of tannins, either in experimental or in grazing conditions, have been conducted in sheep and show a reduction in nematode burdens, worm female fecundity and faecal egg count(s) (FEC) when a moderate concentration of CT are consumed (Niezen et al., 1998a,b, 2002a,b; Athanasiadou et al., 2000a,b, 2001a,b). There are also some studies carried out with goats fed plants supplied or not with CT (Madibela and Jansen, 2003). As previously described for sheep, a reduction in egg excretion and in the fecundity of the female worms have been reported in goats experimentally infected with Haemonchus contortus (Paolini et al., 2003a). A rise in FECs has also been observed in naturally infected goats given polyethylene glycol, a tannin-binding agent that inhibits the effects of tannins (Kabasa et al., 2000).

Tannin-rich heather (shrub species belonging to the Ericaceae family, such as Erica sp. or Calluna vulgaris) is frequent in the botanical composition of natural vegetation mountain communities of humid temperate areas such as northern Spain (Frutos et al., 2002). The availability of these shrub species, together with areas of improved grass-legume pastures, could be an effective tool to achieve the sustainability of ruminant production systems (Osoro et al., 1999) and animal welfare in these marginal mountain areas.

The objective of the present study was to investigate the effect of heather supplementation on FECs of gastrointestinal nematodes and live-weight changes in local Celtiberic and Cashmere goats grazing perennial ryegrass/white clover (Lolium perenne/Trifolium repens) pastures.

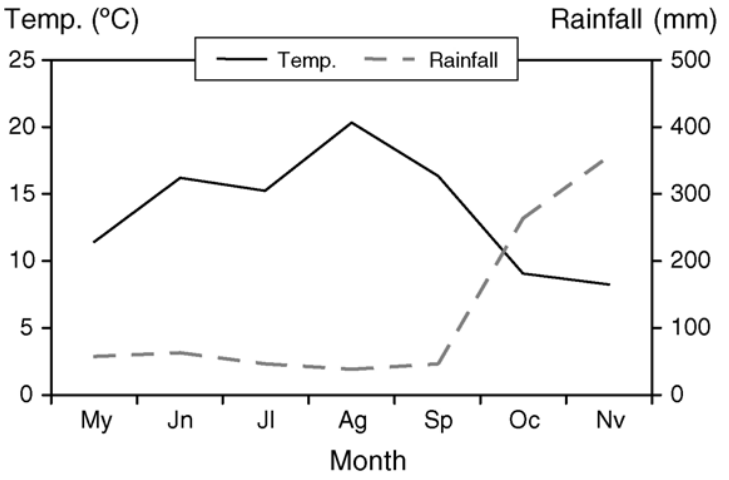

Fig. 1. Monthly mean temperatures and rainfalls at the experimental farm in Illano during the grazing season of 2003.

\section{Material and methods}

\subsection{Experimental site}

The experiment was carried out on a mountain area ( $1000 \mathrm{~m}$ above sea level) in the north-west of Spain $\left(6^{\circ} 53^{\prime} \mathrm{W}, 43^{\circ} 21^{\prime} \mathrm{N}\right.$; Sierra de San Isidro, Illano, Asturias) where shrubby heather-gorse vegetation is dominant. Two plots of 10,550 and $9050 \mathrm{~m}^{2}$ were established where vegetation had been improved in 2001 by dressing and sowing perennial ryegrass (Lolium perenne) and white clover (Trifolium repens).

Annual rainfall in the experimental year was $1996 \mathrm{~mm}$. Rainfall for the experimental season (June-November) is shown in Fig. 1. Mean rainfall ranged from 40 to $62 \mathrm{~mm} / \mathrm{month}$ and increased significantly to 253 and $357 \mathrm{~mm}$ in October and November, respectively. The maximum mean temperature was in August $\left(20.3^{\circ} \mathrm{C}\right)$ and the lowest mean temperature in November $\left(8.2^{\circ} \mathrm{C}\right)$.

\subsection{Animals}

A total of 48 dry goats including 16 adult local Celtiberic does and 32 Cashmere does (21 adult and 11 young female kids, less than year old) were used in this study (Table 1). They were reared outdoors under pasture conditions not excluding nematode infections. The local goats (adult) showed a larger body size $(54.2 \mathrm{~kg}$; S.D. 6.93) than the adult Cashmere does $(32.9 \mathrm{~kg}$; S.D. 8.08). The mean live weight of the young Cashmere females was $19.3 \mathrm{~kg}$ (S.D. 2.6). Therefore, Cashmere goats showed a higher variability. Two weeks before the experiment started all animals were dosed orally with ivermectin $\left(\mathrm{Oramec}^{\circledR}\right.$, Merial) at two times the recommended dose rate. 
Table 1

Mean live weight (LW) and faecal gastrointestinal nematode egg counts (FEC) in local Celtiberic and Cashmere goats grazing ryegrass/white clover pastures without supplementation or supplemented with heather, during the experimental grazing period (from June to November)

\begin{tabular}{|c|c|c|c|c|c|c|c|c|c|}
\hline & \multicolumn{6}{|c|}{ Treatment (T), Breed (B) and Age } & \multicolumn{3}{|c|}{ Significance } \\
\hline & \multicolumn{3}{|c|}{ Pasture (P) } & \multicolumn{3}{|c|}{ Pasture + heather $(\mathrm{P}+\mathrm{H})$} & \multirow[t]{2}{*}{$\mathrm{T}^{\mathrm{a}}$} & \multirow[t]{2}{*}{$\mathrm{B}^{\mathrm{b}}$} & \multirow[t]{2}{*}{$\mathrm{Age}^{\mathrm{c}}$} \\
\hline & Local & $\mathrm{AC}$ & $\mathrm{YC}$ & Local & $\mathrm{AC}$ & $\mathrm{YC}$ & & & \\
\hline$n$ & 8 & 10 & 6 & 8 & 11 & 5 & & & \\
\hline Initial LW (kg) & 54.6 & 32.6 & 20.3 & 53.9 & 33.2 & 17.6 & NS & $* * *$ & $* * *$ \\
\hline LW change (g/day) & -76 & -6 & 12 & -49 & -2 & 12 & $P<0.1$ & $* * *$ & $P<0.1$ \\
\hline \multicolumn{10}{|l|}{ FEC (epg) } \\
\hline June & 57 & 30 & 48 & 14 & 17 & 12 & NS & NS & NS \\
\hline July & 44 & 44 & 114 & 57 & 27 & 25 & NS & NS & $P<0.1$ \\
\hline August & 144 & 319 & 164 & 136 & 118 & 162 & $*$ & NS & NS \\
\hline September & 481 & 928 & 736 & 193 & 495 & 612 & $* * * *$ & $* * *$ & NS \\
\hline October & 1375 & 1906 & 1943 & 686 & 1200 & 1262 & $*$ & NS & NS \\
\hline November & 2821 & 3244 & 3621 & 2629 & 2082 & 2412 & $P<0.1$ & NS & NS \\
\hline
\end{tabular}

AC, adult Cashmere; YC, young Cashmere; NS, $P>0.10$.

${ }^{\text {a }} \mathrm{P}$ vs. $\mathrm{P}+\mathrm{H}$ for adult goats.

${ }^{b}$ Local vs. AC.

${ }^{c}$ AC vs. YC.

${ }^{*} P<0.05$.

${ }^{* * *} P<0.001$.

\subsection{Experimental design}

Twenty-four goats (8 local Celtiberic does and 16 Cashmere does) were randomly assigned to each treatment group, balanced for live weight and age, and located in each plot. One group (Treatment $\mathrm{P}+\mathrm{H}$ ) received freshly cut heather, ad libitum, every 3 days in the morning, while the other acted as the control group (Treatment P). Heather species included in the supplement were mainly Calluna vulgaris, Erica umbellata and Erica cinerea, changing the percentages of each one over the experimental season. All goats grazed continuously throughout the whole experiment. The trial was conducted in 2003 and extended from June to November, which is the common grazing period in the area.

\subsection{Measurements and procedures}

\subsubsection{Pasture}

2.4.1.1. Height. In order to control grass availability, sward surface height was measured weekly using a HFRO swardstick (Barthram, 1986), taking 100 measurements at random in each plot.

2.4.1.2. Botanical composition. The botanical composition of the pasture was assessed during the summer (July) using a point quadrat (Grant, 1981) and recording 100 vertical hits at random in each plot.
2.4.1.3. Chemical composition. Ash and nitrogen (N) of pasture sampled in July were analysed following the procedures of the Association of Official Analytical Chemists (AOAC, 1990). Crude protein (CP) was calculated as $\mathrm{N} \times 6.25$. Neutral and acid detergent fibre (NDF and ADF) and acid detergent lignin (ADL) were analysed by the method of Van Soest et al. (1991).

\subsubsection{Heather}

2.4.2.1. Botanical composition. Spot samples of the heather offered to the goats were collected each time the heather was cut and pooled once a month for later analysis of chemical composition. All samples were sorted into individual botanical species before being freezedried and ground $(0.5 \mathrm{~mm})$.

2.4.2.2. Chemical composition. Analysis of total tannins was conducted, for each species, following the Folin-Ciocalteu assay in combination with polyvinylpolypyrrolidone (PVPP), as described by Makkar et al. (1993). After removing pigments and fats, total phenols (TP) were extracted using aqueous acetone (70\%). TP extract was then treated with PVPP. After centrifugation, PVPP forms a precipitate with tannins and the supernatant has only simple phenols (SP). The TP content in the first extract (before treatment with PVPP) and SP in the second extract (after treatment with PVPP), were determined using the Folin-Ciocalteu reagent and tannic acid (TA, Merck) as the reference standard. The 
difference between the TP and SP value represents the total tannin content expressed as TA equivalents.

The nutritive quality of monthly pooled heather samples was also analysed following the same procedures mentioned above for pasture.

\subsubsection{Animals}

2.4.3.1. Live weight. All animals were weighed at the beginning and at the end of the experimental grazing season.

2.4.3.2. Parasites. Faecal samples were collected by rectal grab sampling, once a month, to measure gastrointestinal nematode egg excretion. Numbers of gastrointestinal nematode eggs per gram (epg) of faeces (FEC) were estimated using the modified McMaster technique (MAFF, 1978) with sodium chloride as the flotation medium, in which 1 egg counted is equivalent to $15 \mathrm{epg}$ fresh faeces. Gastrointestinal nematode genus present in goat faeces were identified monthly on the basis of infective third-stage larvae obtained by coprocultures (van Wyk et al., 2004). In each sample 200 third-stage larvae were identified.

\subsection{Statistical analysis}

Data were subjected to analysis of variance to study the effect of the two main factors, treatment (heather supplemented versus control) and breed (local Celtiberic versus Cashmere), on FEC ( $\log x+1$ transformed to normalise their distribution) and live-weight changes during the grazing season. Only the adult animals were used to study the breed effect. Within the Cashmere goats, the effect of age (adult versus young female kids) was also analysed. All statistical analyses were performed using the procedures of the SPSS programme (SPSS, 2002).

\section{Results}

\subsection{Sward height}

Available sward height did not differ greatly between the plots during the experimental grazing season despite the differences in June-July, which occurred when there was a high availability of herbage (see Fig. 2). In both treatments, sward height decreased from June to November. Mean sward height over the treatment period was $22.0 \pm 0.73 \mathrm{~cm}$ in June, $12.1 \pm 0.34 \mathrm{~cm}$ in July and $6.6 \pm 0.22 \mathrm{~cm}$ in August. It decreased in September to $5.5 \pm 0.22 \mathrm{~cm}$ and maintained a similar

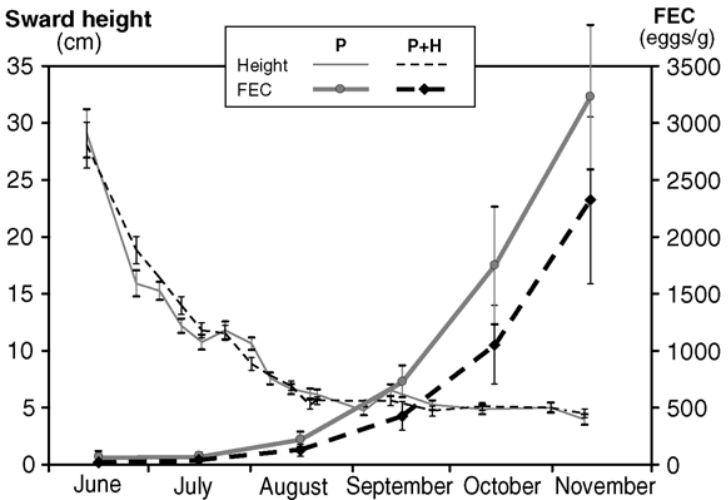

Fig. 2. Faecal gastrointestinal nematode egg counts (FEC) in goats grazing perennial ryegrass/white clover pastures without supplementation $(\mathrm{P})$ or supplemented with heather $(\mathrm{P}+\mathrm{H})$ and sward height evolution during the experimental grazing period (from June to November). Data are shown as mean \pm S.D.

value until the end of the experiment $(4.9 \pm 0.21 \mathrm{~cm}$ in October-November).

\subsection{Botanical and chemical composition of the pasture}

The botanical composition of available pasture was similar between the two plots. Perennial ryegrass accounted for 51 and 58\% cover in $\mathrm{P}$ and $\mathrm{P}+\mathrm{H}$, respectively, while other (not sown) grasses, mainly Agrostis capillaris, accounted for 30 and $26 \%$ cover. The percentage of white clover was 19 and $16 \%$ in $\mathrm{P}$ and $\mathrm{P}+\mathrm{H}$ respectively.

The chemical composition of the pasture showed an acceptable good nutritive quality conditioned by the clover content. Crude protein averaged $16.5 \pm 0.58 \%$ while ADF and NDF accounted for $30.2 \pm 0.54 \%$ and $57.6 \pm 0.63 \%$, respectively. ADL content was very low, averaging $3.1 \pm 0.10 \%$.

\subsection{Botanical and chemical composition of heather}

Heather offered to animals contained basically Erica umbellata (84\%) and Calluna vulgaris (14\%) in June, C. vulgaris (91\%) and Erica cinerea (7\%) in July, and C. vulgaris $(76 \%)$, E. cinerea $(8 \%)$ and E. umbellata $(16 \%)$ in August. In September, the heather supplement was constituted by $C$. vulgaris $(77 \%)$, E. cinerea $(18 \%)$ and E. umbellata (5\%), in October by C. vulgaris $(90 \%)$ and E. cinerea $(9 \%)$ and in November by E. umbellata (45\%), C. vulgaris (39\%) and E. cinerea (16\%).

As expected, the nutritive quality of heather samples analysed was lower than that of ryegrass-clover pasture. No great differences were found over the grazing 


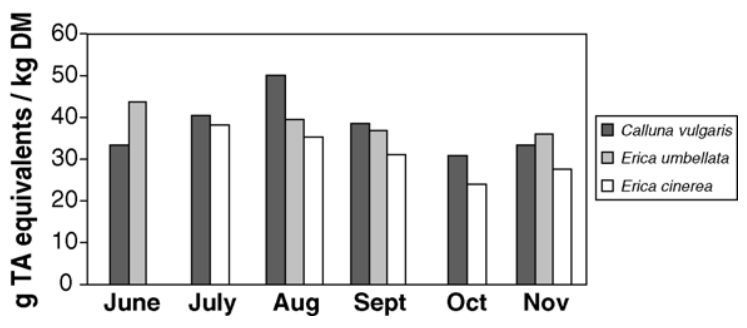

Fig. 3. Tannin contents for each individual species constituting the heather supplement offered to the treated goats during the experimental grazing period (from June to November).

season despite a slight tendency to decrease as the season advanced from June to October. The crude protein content was low, averaging $6.2 \pm 0.10 \%$, while fibre contents were rather high, $\mathrm{ADF}$ accounted for $47.6 \pm 0.81 \%$ and NDF for $56.2 \pm 0.78 \%$. ADL content was also high $(33.9 \pm 0.90 \%)$ in view of the woodiness of these plants.

The tannin content for each individual species is shown in Fig. 3. Total tannin contents did not vary greatly nor were there great differences among the species. Mean contents of total tannins for the heather studied, expressed as g TA equivalents per $\mathrm{kg} \mathrm{DM}$, increased from June to August (42.1, 40.2 and $47.2 \mathrm{~g} / \mathrm{kg}$ DM for June, July and August, respectively) and then decreased during the last 3 months $(37.2,30.2$ and $33.6 \mathrm{~g} / \mathrm{kg} \mathrm{DM}$, for September, October and November, respectively).

\subsection{Live weight}

Changes in live-weight are shown in Table 1. No significant differences in this parameter were observed between goats supplemented or not with heather although supplemented adult goats showed lower liveweights decrease $(P<0.10)$ than unsupplemented ones. All adult animals lost weight, and this reduction was significantly $(P<0.001)$ stronger in the local goats (49-76 g/day) than in Cashmere goats (2-6g/day). Young Cashmere does tended to gain weight during the experimental period ( $12 \mathrm{~g} /$ day for both treatments) and presented significantly better $(P<0.10)$ live weight changes than the adult Cashmere does. Therefore, differences between the breeds were observed in both treatments. However, the interaction treatment $\times$ breed was not significant $(P>0.05)$.

\subsection{Faecal egg counts}

The FEC increased in all goats over the grazing season, following an opposite tendency to sward height. As shown in Fig. 2, the greatest increase was observed after September, when the available sward height was lower

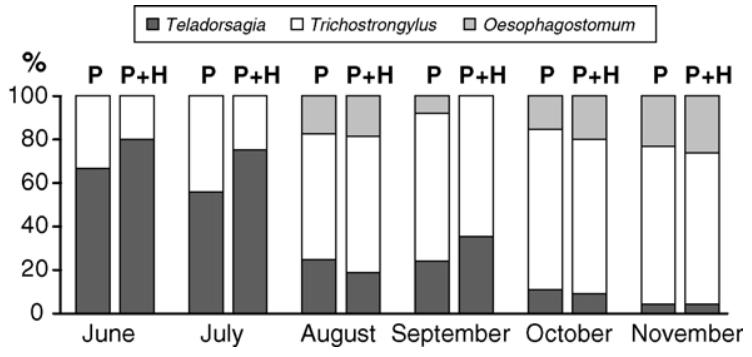

Fig. 4. Nematode genus (\%) identified on third-stage larvae obtained monthly in coprocultures from goats grazing pastures without supplementation $(\mathrm{P})$ or supplemented with heather $(\mathrm{P}+\mathrm{H})$, during the grazing period (from June to November).

than $5-6 \mathrm{~cm}$. Adult goats supplemented with heather showed lower FEC than control goats, and this effect was statistically significant from August $(P<0.05)$ and highly significant $(P<0.001)$ in September. It is worth mentioning that two does from the control group presented FECs of 3600 and 5500 epg and died in October before the last sampling, reducing the differences in FEC between groups at that moment. In September, significantly $(P<0.001)$ higher FECs were found in Cashmere than in the local Celtiberic does. In November, however, even higher FECs were found in local does although this was not statistically significant. A higher increase in FEC between October and November was hence observed in local does. In general, there were no significant differences in FEC between young and adult Cashmere does, with the exception of a tendency $(P<0.10)$ in July for this to be higher in young animals.

\subsection{Coprocultures}

Nematode genera, identified on third-stage larvae obtained from monthly coprocultures, are shown in Fig. 4. Teladorsagia, Trichostrongylus and Oesophagostomum genera were identified. The percentage of Trichostrongylus increased during the grazing period (from $33 \%$ in June to $72 \%$ in November), while that of Teladorsagia decreased (from $67 \%$ in June to $5 \%$ in November). Oesophagostomum was only detected, at low levels, after midsummer. No differences among nematode genera due to treatments were found.

\section{Discussion}

The majority of in vivo studies on the effects of CT on gastrointestinal nematode populations have been performed in experimentally infected sheep and showed that the consumption of tannins could affect the biology of the gastrointestinal nematodes, mainly by decreasing 
FECs, and could, therefore, contribute to modulate the epidemiology of these parasitic diseases (Niezen et al., 1998a,b, 2002a,b; Butter et al., 2000; Athanasiadou et al., 2000a,b, 2001a,b). Less data are available for goats (Kabasa et al., 2000; Paolini et al., 2003a,b) despite their differences in feeding behaviour, metabolism and digestive physiology, and their better adaptation to exploit tanniferous plants (Osoro et al., 2000). In the present study, we investigated the effects of tannins existing in heather on an established population of adult gastrointestinal nematodes and indirectly on incoming third-stage larvae in goats at pasture. The reduction in nematode egg excretion observed in Cashmere and Celtiberic goats supplemented with heather when compared to control is in agreement with recent reports that showed reduced FECs in goats experimentally infected with H. contortus (Paolini et al., 2003a) and Teladorsagia circumcincta and Trichostrongylus colubriformis (Paolini et al., 2003b) fed with CT. Differences in FEC were evident from August to September in the treated groups and the lowest level of egg output after heather administration (40-50\%) was comparable to that observed in previously mentioned reports (50-60\%). The lower FEC could have a double origin, either as a consequence of a reduction in the nematode burden or a lower fecundity of female worms. Previous studies reported the absence of an effect of tannins on nematode numbers after they had been established in goats (Paolini et al., 2003b). However, under tropical conditions, a significant reduction in FECs $(34 \%)$ and nematode numbers was found in goats experimentally infected with $H$. contortus which received dried leaves of Acacia karoo (Kahiya et al., 2003), a plant rich in tannins.

Athanasiadou et al. (2001a) demonstrated that the effect of tannins on nematode populations in sheep varied according to nematode species. In experimentally infected sheep supplemented with quebracho condensed tannins extract $(8 \%)$, a worm burden reduction was observed in T. colubriformis but not in $H$. contortus or $T$. circumcincta. Concerning the fecundity of female nematodes, a decrease was reported for $T$. colubriformis, $T$. circumcincta and $H$. contortus in goats (Paolini et al., 2003a,b) and for T. colubriformis in sheep (Athanasiadou et al., 2000a, 2001a). In addition, CT could also possibly influence incoming larvae (Paolini et al., 2003b). However, the mechanisms responsible for the effects of tannins remain unclear.

Variability in the feeding behaviour and in the ability to exploit plants rich in tannins, such as bushes or shrubs, has been associated with changes in the level of gastrointestinal nematode infections related to interracial and individual levels. Thus, when comparing the trichostrongylid infection level of Angora and French Alpine goats, this was observed to be significantly higher in the Angora than in the Alpine goats (Hoste et al., 2001), possibly related to the feeding or grazing behaviour. The proportion of browsing was much higher in the Alpine than in Angora goats, which spent most of their time grazing. This negative relationship between the time spent browsing and the FEC was also observed at the individual level. In the present study, no clear significant differences in FEC between local and Cashmere goats were found, despite the higher intake of woody plants by local goats compared to Cashmere goats (unpublished data). However, in other experimental conditions the percentage of heather cover in the plot was found to have a significant effect on the FEC (Osoro et al., 2000). It is thought that a low (10-20) percentage of heather in the diet could be sufficient to reduce FEC. Working with sheep, Athanasiadou et al. (2000a) and Butter et al. (2000) found that parasitized sheep offered a food that contained CT at up to $6 \%$ of their food intake, and presented a lower FEC compared to sheep offered the same diet but without CT.

The reduction in FEC found in our study can not be attributed to the positive effect of extra protein availability for the goats supplemented with heather (Coop and Kyriazakis, 2001), because of the low protein content of heather $(5-7 \%)$ unlike other species (e.g. herbaceous legumes as Lotus spp.) with a high content in tannins but also in protein (15-20\%). Nevertheless, the possibility of increasing protein availability in ruminants, e.g. through preventing dietary protein degradation in the rumen due to the CT effect (Waghorn et al., 1987; Frutos et al., 2002), could affect parasitism level and performance.

Anti-nutritional effects of tannins were neither expected nor observed in the present experiment. Although it is well known that high concentrations of tannins ( $>9 \%$ of DM) impair ruminant nutrition and, consequently, ruminant production (Barry, 1985; Athanasiadou et al., 2000a), beneficial effects of tannins when consumed in moderate amounts have been also reported (e.g. Aerts et al., 1999; Barry and McNabb, 1999; Min et al., 2003). In the present work, goats supplemented with heather tended to have improved live weight scores than those which received no heather, mainly in the case of the local goats. The tannin content of the heather used as supplement was sufficient low (3-4\%) to prevent the development of detrimental effects.

Tannin contents were lower than those (6-12\%) expected from previous analyses in similar species (Frutos et al., 2002; Hervás et al., 2003), which could be due to the type of sample analysed. Thus, while pre- 
vious analyses had been performed on samples of small new shoots, samples of the heather used in this experiment correspond to plant parts with a greater proportion of old stems. In general, tannins are more abundant in the parts of the plant that are most 'valuable' to it, e.g. new leaves and flowers (Robbins et al., 1987), and so the higher proportion of other parts, e.g. stems, correlates with a lower tannin content.

The negative mean live weight changes for the all-grazing season are related with the low mean sward height already available in September $(5.5 \mathrm{~cm})$ until the end of the grazing season (November). Merchant (1995) concluded that where goats graze alone, taller swards are likely to be necessary, and a sward height of $6 \mathrm{~cm}$ appears to be an acceptable minimum. Live weight decrease in breeds with bigger body size, under low pasture availability conditions, interaction between breed (different body size) and vegetation availability (quantity and quality) has been observed previously in goats grazing heather-gorse natural communities (Celaya et al., 2004) and in sheep (grazing AgrostisFestuca-Nardus-Calluna) (Osoro et al., 1999) or in perennial ryegrass-white clover pastures (Osoro et al., 2002).

Therefore, the results of this work on reduced FEC and improved live weight changes, are in agreement with those reported by Niezen et al. (1998a,b) and Marley et al. (2003), who working with sheep naturally infected with helminths that had access to tanniferous pastures containing medium to high concentrations of CT, showed reduced FEC, parasite burden and improved performance compared to sheep grazing on tannin-free pastures. In conclusion, the current approach to investigate the effects of heather supplements on the gastrointestinal nematode population in naturally infected goats supports the hypothesis that the availability of heather reduces the FEC in goats grazing ryegrass/white clover pastures and could improve their live weight changes, but further studies are needed to confirm this. Thus, for example, in order to advance in this field, it would be necessary to estimate the proportion of heather incorporated in the goats diet to be able to accurately establish the relationship between heather tannin intake, parasitism and animal performance.

\section{Acknowledgements}

Funding for this work was provided by a research grant from the Spanish Agricultural Research Institute (INIA) (RTA-01-014). Ignacio Ferre was financed by the Ramón y Cajal Spanish Scientific Programme.

\section{References}

Aerts, R.J., Barry, T.N., McNabb, W.C., 1999. Polyphenols and agriculture: beneficial effects of proanthocyanidins in forages. Agric. Ecosyst. Environ. 75, 1-12.

AOAC, 1990. Official Methods of Analysis, 14th ed. Association of Official Analytical Chemists, Washington, DC.

Athanasiadou, S., Kyriazakis, I., Jackson, F., Coop, R.L., 2000a. Consequences of long-term feeding with condensed tannins on sheep parasitised with Trichostrongylus colubriformis. Int. J. Parasitol. 30, 1025-1033.

Athanasiadou, S., Kyriazakis, I., Jackson, F., Coop, R.L., 2000b. Effects of short-term exposure to condensed tannins on adult Trichostrongylus colubriformis. Vet. Rec. 146, 728-732.

Athanasiadou, S., Kyriazakis, I., Jackson, F., Coop, R.L., 2001a. Direct anthelmintic effects of condensed tannins towards different gastrointestinal nematodes of sheep: in vitro and in vivo studies. Vet. Parasitol. 99, 205-219.

Athanasiadou, S., Kyriazakis, I., Jackson, F., Coop, R.L., 2001b. The effects of condensed tannins supplementation of foods with different protein content on parasitism, food intake and performance of sheep infected with Trichostrongylus colubriformis. Br. J. Nutr. 86, 697-706.

Athanasiadou, S., Kyriazakis, I., Jackson, F., 2003. Can plant metabolites have a role in controlling gastrointestinal nematode parasitism in small ruminants? In: VI International Symposium on the Nutrition of Herbivores. Proceedings of the Satellite Symposium on Secondary Compounds and Browse Utilization, Universidad Autonoma Yucatán, Mérida, México, pp. 16-25.

Barry, T.N., 1985. The role of condensed tannins in the nutritional value of Lotus pedunculatus for sheep. Rates of body and wool growth. Br. J. Nutr. 54, 211-217.

Barry, T.N., McNabb, W.C., 1999. The implications of condensed tannins on the nutritive value of temperate forages fed to ruminants. Br. J. Nutr. 81, 263-272.

Barthram, G.T., 1986. Experimental techniques: the HFRO swardstick. In: The Hill Farming Research Organisation Biennial Report, 1984-85. H.F.R.O., Bush Estate, Penicuik, Midlothian, UK, pp. 29-30.

Butter, N.L., Dawson, J.M., Wakelin, D., Buttery, P.J., 2000. Effect of dietary tannin and protein concentration on nematode infection (Trichostrongylus colubriformis) in lambs. J. Agric. Sci. 134, 89-99.

Celaya, R., Jáuregui, B.M., García, U., Osoro, K., 2004. Live weight changes and vegetation dynamics in heathland communities grazed by Cashmere or local goats. In: 8th International Conference on Goats, IGA, Pretoria, South Africa.

Coop, R.L., Kyriazakis, I., 2001. Influence of host nutrition on the development and consequences of nematode parasitism in ruminants. Trends Parasitol. 17, 325-330.

Frutos, P., Hervás, G., Ramos, G., Giraldez, F.J., Mantecón, A.R., 2002. Condensed tannin content of several shrub species from a mountain area in northern Spain and its relationship to various indicators of nutritive value. Anim. Feed Sci. Technol. 95, 215-226.

Grant, S.A., 1981. Sward components. In: Hodgson, J., Baker, R.D., Davies, A., Laidlaw, A.S., Leaver, J.D. (Eds.), Sward Measurement Handbook. BGS, Hurley, Maidenhead, Berkshire, UK, pp. 71-92.

Hervás, G., Mandaluniz, N., Oregui, L.M., Mantecón, A.R., Frutos, P., 2003. Evolución anual del contenido de taninos del brezo (Erica vagans) y relación con otros parámetros indicativos de su valor nutritivo. ITEA Prod. Anim. 99A, 69-84. 
Hoste, H., Leveque, H., Dorchies, Ph., 2001. Comparison of nematode infections of the gastrointestinal tract in Angora and dairy goats in a rangeland environment: relations with the feeding behaviour. Vet. Parasitol. 101, 127-135.

Houdijk, J.G.M., Athanasiadou, S., 2003. Direct and indirect effects of host nutrition on ruminant gastrointestinal nematodes. In: Mannetje, L.'t., Ramírez, L., Sandoval-Castro, C., Ku-Vera, J.C. (Eds.), VI International Symposium on the Nutrition of Herbivores. Matching herbivore nutrition to ecosystems biodiversity. Universidad Autonoma Yucatán, Mérida, México, pp. 213-236.

Jackson, F., Coop, R.L., 2000. The development of anthelmintic resistance in sheep nematodes. Parasitology 120, 95-107.

Kabasa, J.D., Opuda-Asibo, J., Ter Meulen, U., 2000. The effect of oral administration of polyethylene glycol on faecal helminth egg counts in pregnant goats grazed on browse containing condensed tannins. Trop. Anim. Health Prod. 32, 73-86.

Kahiya, C., Mukaratirwa, S., Thamsborg, S.M., 2003. Effects of Acacia nilotica and Acacia karoo diets on Haemonchus contortus infection in goats. Vet. Parasitol. 115, 265-274.

Madibela, O.R., Jansen, K., 2003. The use of indigenous parasitic plant (Viscum verrucosum) in reducing faecal egg counts in female Tswana goats. Livest. Res. Rural Dev. 15 (9), http://www.cipav.org.co/lrrd/lrrd15/9/madi159.htm.

MAFF, 1978. Manual of Veterinary Parasitological Techniques. Technical Bulletin No. 18. Ministry of Agriculture, Fisheries and Food, London.

Makkar, H.P.S., Blummel, M., Borowy, N.K., Becker, K., 1993. Gravimetric determination of tannins and their correlations with chemical and protein precipitation methods. J. Sci. Food Agric. 61, 161-165.

Marley, C.L., Cook, R., Keatinge, R., Barret, J., Lampkin, N.H., 2003. The effect of birdsfoot trefoil (Lotus corniculatus) and chicory (Cichorium intybus) on parasite intensities and performance of lambs naturally infected with helminth parasites. Vet. Parasitol. $112,147-155$.

McKellar, Q.A., 1997. Ecotoxicology and residues of anthelmintic compounds. Vet. Parasitol. 72, 413-435.

Merchant, M., 1995. Herbage intake and diet selection by goats in relation to their management on sown swards and rush/grass mixtures. In: Laker, J.P., Russel, A.J.F. (Eds.), The Nutrition and Grazing Ecology of Speciality Fibre Producing Animals. MLURI, Aberdeen, UK, pp. 127-140, European Fine Fibre Network Occasional Publication No. 3.

Min, B.R., Barry, T.N., Attwood, G.T., McNabb, W.C., 2003. The effect of condensed tannins on the nutrition of ruminants fed fresh temperate forages: a review. Anim. Feed Sci. Technol. 106, 3-19.

Niezen, J.H., Robertson, H.A., Waghorn, G.C., Charleston, W.A.G., 1998a. Production, faecal egg counts and worm burdens of ewe lambs which grazed six contrasting forages. Vet. Parasitol. 80, $15-27$.

Niezen, J.H., Waghorn, G.C., Charleston, W.A.G., 1998b. Establishment and fecundity of Ostertagia circumcincta and Trichostrongylus colubriformis in lambs fed lotus (Lotus pedunculatus) or perennial ryegrass (Lolium perenne). Vet. Parasitol. 78, 13-21.

Niezen, J.H., Charleston, W.A.G., Robertson, H.A., Shelton, D., Waghorn, G.C., Green, R., 2002a. The effect of feeding sulla (Hedysarum coronarium) or lucerne (Medicago sativa) on lamb parasite burdens and development of immunity to gastrointestinal nematodes. Vet. Parasitol. 105, 229-245.

Niezen, J.H., Waghorn, G.C., Graham, T., Carter, J.L., Leathwick, D.M., 2002b. The effect of diet fed to lambs on subsequent development of Trichostrongylus colubriformis larvae in vitro and on pasture. Vet. Parasitol. 105, 269-283.

Osoro, K., Olivan, M., Celaya, R., Martínez, A., 1999. Effects of genotype on the performance and intake characteristics of sheep grazing contrasting hill vegetation communities. Anim. Sci. 69, 419-426.

Osoro, K., Celaya, R., Martínez, A., 2000. The effect of grazing management of sheep and goats on animal performance and vegetation dynamics in partially improved heath-gorse vegetation. In: Rook, A.J., Penning, P.D. (Eds.), Grazing Management. BGS Occasional Symposium No. 34, pp. 135-140.

Osoro, K., Martínez, A., Celaya, R., 2002. The effect of breed and sward height on sheep performance and production per hectare during the spring and autumn in Northern Spain. Grass Forage Sci. 57, 137-146.

Paolini, V., Bergeaud, J.P., Grisez, C., Prevot, F., Dorchies, Ph., Hoste, H., 2003a. Effects of condensed tannins on goats experimentally infected with Haemonchus contortus. Vet. Parasitol. 113, 253-261.

Paolini, V., Frayssines, A., De la Farge, F., Dorchies, Ph., Hoste, H., 2003b. Effects of condensed tannins on established populations and on incoming larvae of Trichostrongylus colubriformis and Teladorsagia circumcincta in goats. Vet. Res. 34, 331-339.

Robbins, C.T., Hanley, T.A., Hagerman, A.E., Hjeljord, O., Baker, D.L., Schartz, C.C., Mautz, W.W., 1987. Role of tannins in defending plants against ruminants: reduction in protein availability. Ecology $68,98-107$.

SPSS, 2002. Guía breve del SPSS 1.5. SPSS Inc., Ireland.

Van Soest, P.J., Robertson, J.B., Lewis, B.A., 1991. Methods for dietary fiber, neutral detergent fiber, and nonstarch polysaccharides in relation to animal nutrition. J. Dairy Sci. 74, 3583-3597.

van Wyk, J.A., Cabaret, J., Michael, L.M., 2004. Morphological identification of nematode larvae of small ruminants and cattle simplified. Vet. Parasitol. 119, 277-306.

Waghorn, G.C., Ulyatt, M.J., John, A., Fisher, M.T., 1987. The effects of condensed tannins on the site of digestion of amino acids and other nutrients in sheep fed on Lotus corniculatus L. Br. J. Nutr. 57, 115-126. 